\title{
Pengembangan Kawasan Perdesaan Berbasis Tanaman Pangan di Kecamatan Amuntai Utara Kabupaten Hulu Sungai Utara
}

\section{(Development of Rural Areas Based on Food Plants in Amuntai Utara District Hulu Sungai Utara Regency)}

\author{
Faisal Azmi $^{1)}$, Azwar Saihani' ${ }^{2)}$ dan Heldawati ${ }^{3)}$ \\ Program Studi Agribisnis Sekolah Tinggi Ilmu Pertanian Amuntai \\ 1)faisal.fs2908@gmail.com \\ 2)Azwar.saihani63@yahoo.com \\ ${ }^{3)}$ heldawati006@gmail.com
}

\begin{abstract}
ABSTRAK
Penelitian ini bertujuan untuk mengetahui(i) keunggulan komparatif komoditas tanaman pangan dan sektor basis tanaman pangan, (ii) keunggulan kompetitif komoditas tanaman pangan dan sektor kompetitif dan non kompetitif, (ii) kekuatan, kelemahan, peluang dan ancaman pengembangan kawasan perdesaan berbasis tanaman pangan di Kecamatan Amuntai Utara Kabupaten Hulu Sungai Utara. Penelitian dilakukan pada November 2018 - Januari 2019 di Kecamatan Amuntai Utara Kabupaten Hulu Sungai Utara dengan metode penelitian yang digunakan adalah metode deskriptif kualitatif dan kuantitatif. Berdasarkan hasil penelitian didapatkan nilai LQ di Kecamatan Amuntai Utara memiliki sektor basis dan sektor non basis pada komoditas tanaman pangan; analisis shift share menunjukkan bahwa komoditas unggulan kompetitif tanaman pangan padi dengan nilai 0,12 dan jagung dengan nilai 0,56; analisis SWOT diperoleh dari analisis faktor internal (IFAS) sebesar 2,832 dan analisis faktor eksternal (EFAS) sebesar 2,45, maka pengembangan kawasan perdesaan berbasis tanaman pangan tersebut berada di kuadran I (mendukung strategi agresif).
\end{abstract}

Kata Kunci: Keunggulan, komoditas, kompetitif, pengembangan, kawasan.

\section{ABSTRACT}

This study aims to determine (i) the comparative advantage of food crop commodities and food crop base sectors, (ii) competitive advantages of food crops and competitive and non-competitive areas, (ii) strengths, weaknesses, opportunities, and threats of rural food-based rural development in Amuntai Utara District, Hulu Sungai Utara Regency. The study was conducted on November 2018 January 2019 in Amuntai Utara District Hulu Sungai Utara Regency with the research method used was descriptive qualitative and quantitative methods. Based on the results of the study, the LQ value in the North Amuntai Subdistrict has a base sector and non-base sector in food crop commodities; shiftshare analysis shows that competitive commodities of rice food plants with a value of 0.12 and corn with a value of 0.56; SWOT analysis was obtained from an analysis of internal factors (IFAS) of 2,832 and external factor analysis (EFAS) of 2,45, hence the development of rural areas based on food crops was in quadrant I (supporting aggressive strategies).

Keywords: Excellence, commodity, competitive, development, region.

\section{PENDAHULUAN}

Indonesia dikenal sebagai negara agraris yang berarti negara yang mengandalkan sektor pertanian baik sebagai sumber mata pencaharian maupun sebagai dasar atau pondasi bagi pembangunan di Indonesia. Namun selama ini, kegiatan ekonomi yang memanfaatkan kekayaan sumber daya alam baru dalam bentuk pembangunan produksi dibidang pertanian atau budidaya saja yang merupakan salah satu sub sistem agribisnis. Pengelolaan pertanian tidak akan mampu menjadi tulang punggung atau dasar dari pembangunan ekonomi jika hanya terbatas pada produksi atau budidaya pertanian. Pembangunan perdesaan merupakan titik penting dalam 
pembangunan Indonesia. Jika dilihat dari jumlah penduduk yang tinggal di perkotaan memang lebih banyak dibandingkan penduduk yang tinggal di wilayah perdesaan. Namun masalah kependudukan yang komplek lebih banyak terjadi di perdesaan seperti kemiskinan (Burano, 2017).

Produktivitas Tanaman Pangan di Kabupaten Hulu Sungai Utara. Rata-rata produksi tanaman pangan Kabupaten Hulu Sungai Utara lebih rendah dibandingkan dengan rata-rata produksi Provinsi Kalimantan Selatan sehingga perlu dilakukan peningkatan produksi. Rata-rata produksi tanaman pangan di Kecamatan Amuntai Utara dapat dilihat pada Gambar 1 berikut ini.

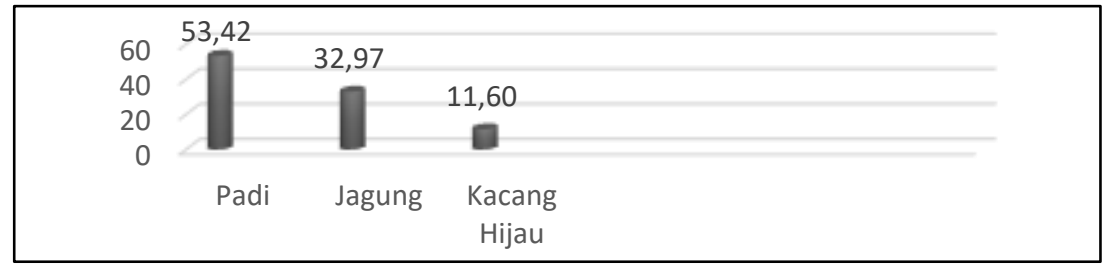

Gambar 1. Rata-rata Produksi Tanaman Pangan di Kecamatan Amuntai Utara Tahun 2018.

Berdasarkan Gambar 1 di atas menunjukkan bahwa produksi tanaman pangan di Kabupaten Hulu Sungai Utara berbasis di Kecamatan Amuntai Utara, yang menjadi objek penelitian ini. Dari gambar 1 di atas maka rata-rata produksi tanaman padi di Kecamatan Amuntai Utara sebanyak 53,42 kw/ha, untuk produksi tanaman jagung sebanyak $32,97 \mathrm{kw} / \mathrm{ha}$, dan untuk produksi tanaman kacang hijau sebanyak 11,60 kw/ha (Dinas Pertanian Kabupaten Hulu Sungai Utara, 2018).

Potensi pengembangan sektor pertanian di Kecamatan Amuntai Utara cukup besar dilihat dari ketersediaan lahan pertanian. Selain itu dapat dibandingkan dengan kecamatan lainnya di wilayah Kabupaten Hulu Sungai Utara produksi tanaman pangan yang berbasis di Kecamatan Amuntai Utara hasil produksinya sangatlah bervariasi. Menurut Tarigan (2005) teori basis dapat menunjukkan bahwa laju pertumbuhan ekonomi wilayah dapat ditentukan oleh besarnya peningkatan ekspor dari wilayah yang memiliki komoditas basis sehingga dapat mendorong pertumbuhan suatu wilayah. Dengan adanya sektor basis, kebijakan ekonomi harus dibuat berbeda antardaerah karena kondisi dan potensi daerah tidak sama satu dengan yang lainnya

Oleh karena itu perlu cara untuk mengetahui strategi pengembangan kawasan perdesaan berbasis tanaman pangan, keunggulan komparatif dan kompetitif dari komoditas tanaman pangan di Kecamatan Amuntai Utara Kabupaten Hulu Sungai Utara. Penelitian ini bertujuan untuk mengetahui(i) keunggulan komparatif komoditas tanaman pangan dan sektor basis tanaman pangan, keunggulan kompetitif komoditas tanaman pangan dan sektor kompetitif dan non kompetitif, (ii) kekuatan, kelemahan, peluang dan ancaman pengembangan kawasan perdesaan berbasis tanaman pangan di Kecamatan Amuntai Utara Kabupaten Hulu Sungai Utara.

\section{METODE PENELITIAN}

\section{Tempat dan Waktu Penelitian}

Penelitian ini dilakukan di Kecamatan Amuntai Utara Kabupaten Hulu Sungai Utara yang dimulai dari bulan November 2018-Januari 2019.

\section{Jenis dan Sumber Data}


Jenis penelitian ini menggunakan sumber-sumber dari data primer dan sekunder. Data primer akan diperoleh melalui wawancara langsung dengan masyarakat yang memiliki usaha terkait komoditas tanaman pangan, ketua kelompok tani, petugas penyuluhan pertanian, sekertaris camat dan petugas dari dinas pertanian Kabupaten Hulu Sungai Utara. Sedangkan Data Sekunder yang diperoleh dari Badan Pusat Statistika Kabupaten Hulu Sungai Utara dan Dinas Pertanian Kabupaten Hulu Sungai Utara.

\section{Metode Pengambilan Sampel}

Sampel pada penelitian ini adalah perwakilan masyarakat yang terkait dengan penelitian ini. Menurut Sugiyono (2012), proporsive sampling adalah teknik penentuan sampel dengan pertimbangan tertentu. Pengambilan sampel dilakukan dengan terlebih dulu menetapkan tujuan dan perencanaan tertentu. Adapun sampel yang terlibatkan dalam penelitian ini berjumlah 10 orang responden yang pekerjaannya terkait dengan penelitian ini meliputi masyarakat yang memiliki usaha terkait komoditas tanaman pangan, ketua kelompok tani, petugas penyuluhan pertanian, sekertaris camat dan petugas dari dinas pertanian Kabupaten Hulu Sungai Utara.

\section{Analisis Data}

Mengetahui tujuan yang pertama yaitu dengan menggunakan analisis Location Quotion (LQ) (Penentuan Komoditas Unggulan Komparatif). Location Quotion (LQ) adalah metode analisis kuantitatif yang merupakan suatu indeks untuk membandingkan komoditas pada tingkat Kabupaten atau Kecamatan dalam aktivitas pertanian budidaya tanaman pangan dengan menentukan komoditas unggulan diantara tanaman lainnya. Adapun untuk mengetahui nilai LQ (Heldawati \& Maisyarah, 2017) digunakan rumus:

$$
\mathrm{LQ}=\frac{\mathrm{pi} / \mathrm{pt}}{\mathrm{Xi} / \mathrm{Xt}}
$$

Dimana :

pi : jumlah tanaman pangan per

$$
\text { kecamatan }
$$

pt : jumlah seluruh tanaman pangan di kecamatan

$\mathrm{Xi}$ : jumlah tanaman pangan di Kabupaten Hulu Sungai Utara

Xt : jumlah seluruh tanaman pangan di Kabupaten Hulu Sungai Utara

Mengetahui tujuan yang kedua yaitu dengan menggunakan analisis Shift Share (penentuan komoditas unggulan kompetitif). Analisis ini menganalisis perubahan berbagai indikator kegiatan ekonomi, seperti produksi dan kesempatan kerja, pada dua titik waktu di suatu wilayah. Hasil analisis ini akan diketahui bagaimana perkembangan suatu sektor di suatu wilayah dibandingkan sektor lainnya dalam konteks wilayah administratif kabupaten. Hasil analisis shift share diperoleh gambaran kinerja aktifitas di suatu wilayah. Gambaran kinerja ini dapat dijelaskan dari 3 komponen hasil analisis, yaitu :

a. Komponen laju pertumbuhan total (Komponen Regional Share).

b. Komponen pergeseran proporsional (Komponen Proportional Shift).

c. Komponen pergeseran diferensial (Komponen Differential Shift).

Persamaan analisis shift share ini adalah sebagai berikut ( Rustiadi, et. al., 2018).

$$
S S \mathbf{A}=\left(\frac{\mathbf{X} \cdot \cdot(\mathbf{t} \mathbf{1})}{\mathbf{X} \cdot \cdot(\mathbf{t} \mathbf{0})}-\mathbf{1}\right)+\left(\frac{\mathbf{X}_{\mathbf{1}_{(\mathbf{t} 1)}}}{\mathbf{X}_{\mathbf{1}_{(\mathbf{t})}}}-\frac{\mathbf{X} \cdot \cdot(\mathbf{t} \mathbf{1})}{\mathbf{X} \cdot \cdot(\mathbf{t} \mathbf{0})}\right)+\left(\frac{\mathbf{X}_{\mathbf{i j}(\mathbf{t} 1)}}{\mathbf{X}_{\mathbf{i j}(\mathbf{t} \mathbf{0})}}-\frac{\mathbf{X}_{\mathbf{i}(\mathbf{t} \mathbf{1})}}{\mathbf{X}_{\mathbf{i}(\mathbf{t} \mathbf{0})}}\right)
$$

A

Dimana :

a $\quad=$ komponen regional share
B

$\mathrm{b} \quad=$ komponen proportional shift 
c = komponen differential shift, dan

$\mathrm{X} . . \quad=$ Nilai total aktifitas wilayah secara agregat

X.i $=$ Nilai total aktifitas tertentu di kecamatan

Xij = Nilai di wilayah kecamatan dan aktifitas di kabupaten

t1 = Titik Tahun Akhir (2018)

t0 = Titik Tahun Awal (2016)

Mengetahui tujuan yang ketiga yaitu dengan menggunakan analisis SWOT. Setelah mengidentifikasi faktor internal dan faktor eksternal yang sudah ditentukan langkah selanjutnya adalah menentukan strategi pengembangan kawasan perdesaan berbasis tanaman pangan dengan analisis SWOT yaitu menganalisis faktor internal dan faktor eksternal untuk mengetahui kekuatan, kelemahan, peluang dan ancaman dalam pengembangan kawasan perdesaan berbasis tanaman pangan di Kecamatan Amuntai Utara. Analisis ini dilakukan dengan tahapan sebagai berikut (Rangkuti, 2008).

1. Pengumpulan data

1) Data Internal yang terdiri dari kekuatan dan kelemahan.

2) Data Eksternal yang terdiri dari peluang dan ancaman.

2. Penyusunan matriks Faktor Strategi Internal (IFAS) dan Faktor Strategi Eksternal (EFAS).

Penentuan Bobot Setiap Variabel
Penentuan bobot pada analisis faktor internal dan faktor eksternal dilakukan dengan cara mengajukan pertanyaan pada responden. Penentuan bobot setiap variabel digunakan skala 1,2 dan 3 dengan keterangan skala sebagai berikut:

$1=$ Jika indikator horizontal kurang penting dari indikator vertikal.

$2=$ Jika indikator horizontal sama penting dari indikator vertikal.

$3=$ Jika indikator horizontal lebih penting dari indikator vertikal.

\section{HASIL DAN PEMBAHASAN}

\section{Hasil}

\section{Penentuan Sektor Unggulan Komparatif}

Penentuan sektor unggulan komparatif dilakukan dengan dasar pemikiran metode dan dasar teori Location Quotient (LQ) yaitu mengidentifikasi sektor sektor pembangunan yang termasuk sektor basis maupun non basis pada suatu daerah. Hasil analisis LQ ini mampu menentukan sektor basis pada kawasan perdesaan dalam perekonomian wilayah, dengan indikator yang harus menunjukkan kekuatan peranan suatu sektor dalam daerah yaitu wilayah kecamatan dibandingkan dengan peranan sektor yang sama pada perdesaan di Kecamatan Amuntai Utara. Hasil analisis lq kawasan perdesaan tahun 2018 dapat dilihat pada Tabel 1 berikut ini.

Tabel 1. Hasil Analisis LQ Kawasan Perdesaan Tahun 2018

\begin{tabular}{llcccc}
\hline \multirow{2}{*}{ Kecamatan } & \multicolumn{4}{c}{ LOCATION QUOTIENT (LQ) } \\
\cline { 2 - 5 } & Padi & Jagung & Kacang Tanah & Kacang Hijau \\
\hline 1. & Danau Panggang & 1,01 & 0 & 0 & 0 \\
2. Paminggir & 1 & 0 & 0 & 0 \\
3. & Babirik & 1 & 0,5 & 0 & 0 \\
4. & Sungai Pandan & 1 & 0,75 & 0 & 0 \\
5. Sungai Tabukan & 1,01 & 0,5 & 0 & 5,65 \\
6. Amuntai Selatan & 1,01 & 0 & 0 & 0 \\
7. Amuntai Tengah & 0,98 & 2,75 & 8 & 0 \\
8. & Banjang & 1 & 1 & 1 & 0 \\
9. Amuntai Utara & 1 & 2,25 & 0 & 5,35 \\
10. Haur Gading & 1,01 & 0,25 & 0 & 0 \\
\hline
\end{tabular}

Sumber : Hasil Analisis LQ Tahun 2018 
Keterangan : $\quad$ LQ>1 maka sektor basis LQ $<1$ maka sektor non basis $\mathrm{LQ}=1$ maka sektor non basis
Berdasarkan pada Tabel 1 di atas menunjukkan bahwa hasil analisis LQ menunjukkan bahwa sektor basis disetiap kecamatan berbeda. Kecamatan Amuntai Utara memiliki sektor basis dan sektor non basis, pada komoditas tanaman pangan seperti tanaman padi bernilai 1 berarti sektor non basis artinya tidak memiliki keunggulan komparatif, komoditas tanaman padi tersebut hanya cukup untuk memenuhi kebutuhan konsumsi diwilayahnya sendiri dan tidak bisa mengekspor ke kecamatan lain. Tanaman jagung bernilai 2,25 berarti sektor basis dan tanaman kacang hijau bernilai 5,35 berarti sektor basis artinya komoditas tanaman pangan seperti jagung dan kacang hijau memiliki keunggulan komparatif, komoditas tamanan tersebut tidak hanya saja dapat memenuhi kebutuhan konsumsi diwilayahnya tetapi juga dapat mengekspor ke luar kecamatan lain, kecuali dengan komoditas tanaman kacang tanah, hal ini berbeda dengan kecamatan Danau Panggang, Babirik, Sungai Pandan, Sungai Tabukan, Amuntai Tengah, Banjang, Haur Gading. Kecamatan Paminggir dan Kecamatan Amuntai Selatan yang memiliki nilai LQ 1,01 hanya pada komoditas padi. Adapun sektor non basis ditunjukan pada komoditas jagung, kacang tanah dan kacang hijau. Kecamatan Paminggir dan kecamatan Amuntai Selatan yang memiliki nilai $\mathrm{LQ}<1$ hanya pada komoditas padi. Sedangkan dengan komoditas dengan nilai LQ>1 memiliki kemampuan untuk dapat mengekspor keluar daerah tersebut.

\section{Penentuan Sektor Unggulan Kompetitif}

Kemampuan

kompetisi (Competitiveness) suatu wilayah dapat diukur dengan Analisis Shift Share. Analisis ini merupakan metode yang digunakan untuk menganalisis struktur perekonomian di suatu wilayah. Selain itu dapat juga digunakan untuk melihat pertumbuhan sektor-sektor perekonomian suatu wilayah selama dua periode. Penentuan sektor kompetitif dilakukan dengan menentukan regional share yang menyatakan pertumbuhan total wilayah pada dua titik waktu yang menunjukkan total wilayah. Regional share pada Kawasan Perdesaan Kecamatan Amuntai Utara diperoleh hasil yang menunjukkan pertumbuhan yang cukup baik dari tahun 2016 dan 2018 dari setiap sub sektor tanaman pangan seperti dapat dilihat pada Tabel 2 berikut ini.

Tabel 2. Hasil analisis Shift Share kawasan perdesaan Tahun 2018

\begin{tabular}{lcccc}
\hline \multicolumn{1}{c}{ Kecamatan } & Padi & Jagung & Kacang Tanah & Kacang Hijau \\
\hline Danau Panggang & 0,56 & 0,00 & $-0,29$ & $-0,6$ \\
Paminggir & 0,48 & 0,72 & $-0,29$ & $-0,6$ \\
Babirik & 0,25 & 2,20 & $-0,29$ & $-0,6$ \\
Sungai Pandan & 0,05 & 0,6 & $-0,29$ & $-0,6$ \\
Sungai Tabukan & 0,16 & 0,74 & $-0,29$ & $-0,5$ \\
Amuntai Selatan & 0,26 & $-1,00$ & $-0,29$ & $-0,6$ \\
Amuntai Tengah & 0,12 & 0,50 & $-0,33$ & $-0,6$ \\
Banjang & 0,00 & 1,80 & 0,24 & -1 \\
Amuntai Utara & 0,12 & 0,56 & $-0,29$ & $-0,5$ \\
Haur Gading & 0,12 & 0,86 & $-0,29$ & $-0,6$ \\
\hline
\end{tabular}

Sumber : Hasil Analisis SSA Tahun 2018

Keterangan : $\quad$ SSA Positif (+) Sektor Kompetitif

SSA Negatif (-) Sektor Non Kompetitif 
Berdasarkan hasil dari analisis shift share menunjukkan bahwa komoditas unggulan kompetitif komoditas tanaman pangan seperti tanaman padi dengan nilai 0,12 dan jagung dengan nilai 0,56 di Kecamatan Amuntai Utara yang menunjukkan bernilai positif (+) artinya komoditas tanaman padi dan jagung dikatakan sektor kompetitif jadi tanaman komoditas tanaman yang sama di kecamatan lain, atau sektor non kompetitif sehingga dapat disimpulkan hanya komoditas tanaman padi, jagung pada seluruh kecamatan penelitian yang merupakan sektor kompetitif.

\section{Penentuan Posisi Dalam Diagram SWOT}

Berdasarkan perhitungan dari
pembobotan tersebut diperoleh skor tersebut bisa bersaing dengan jenis yang sama di kecamatan lainnya. Sedangkan untuk komoditas lain seperti kacang tanah dan kacang hijau yang menunjukkan bernilai negatif (-) artinya komoditas tanaman kacang tanah dan kacang hijau dapat dikatakan tdiak dapat bersaing dengan

kekuatan dan kelemahan sebesar 2,807, sedangkan peluang dan ancaman sebesar 2,45. Hasil tersebut selanjutnya dimasukkan dalam diagram SWOT sehingga akan tahu dimana letak posisi kuadran pengembangan kawasan perdesaan berbasis tanaman pangan di Kecamatan Amuntai Utara Kabupaten Hulu Sungai Utara seperti terlihat pada Gambar 2 berikut ini :

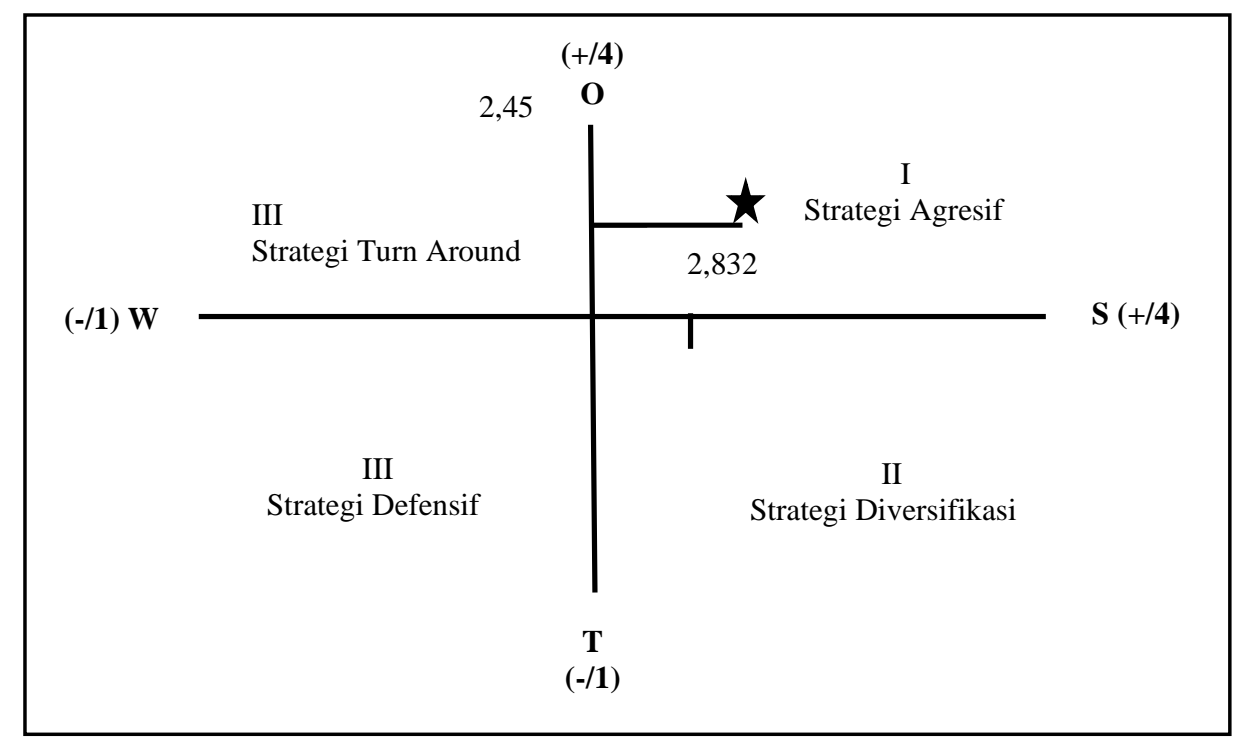

Gambar 2. Penentuan posisi dalam diagram SWOT.

Berdasarkan pada Gambar 2 di atas terlihat bahwa hasil perhitungan matriks internal strategi (IFAS) dengan hasil 2,832 dan matriks eksternal faktor strategi (EFAS) dengan hasil 2,45, maka pengembangan kawasan perdesaaan berbasis tanaman pangan di Kecamatan Amuntai Utara Kabupaten Hulu Sungai Utara berada pada kuadran I (Mendukung
Strategi Agresif). Kuadran I : (SOStrategis) merupakan keadaan yang sangat menguntungkan, karena mempunyai kekuatan dan peluang dalam pengembangan kawasan perdesaan berbasis tanaman pangan tersebut. Selanjutnya hasil dari analisis internal dan eksternal di masukkan dalam matriks SWOT sehingga diketahui strategi apa 
yang dapat diterapkan dalam pengembangan kawasan perdesaaan berbasis tanaman pangan di Kecamatan Amuntai Utara Kabupaten Hulu Sungai Utara. (Strategi SO-Strategi) pengembangan sektor pertanian tanaman pangan berbasis ekonomi lokal. Dengan meningkatkan hasil produksi tanaman pangan, meningkatkan sarana dan prasarana, pengembangan sektor unggulan sesuai dengan permintaan pasar dan potensi wilayah.

\section{Pembahasan}

Pengembangan kawasan perdesaan berbasis tanaman pangan, memiliki kekuatan dan peluang yang tinggi karena kebanyakan bermata pencaharian masyarakat sebagai petani dan didorong dengan lahan pertanian yang cukup luas sehingga cocok untuk para pengusahatani melakukan kegiatan usahatani ditambah dengan banyaknya industri pengolahan yang ada tersebut sehingga memungkinkan para petani untuk mendalami pengelolaan hasil produksinya. (Strategi SO-Strategi) pengembangan sektor pertanian tanaman pangan berbasis ekonomi lokal. Dengan meningkatkan hasil produksi tanaman pangan, meningkatkan sarana dan prasarana, pengembangan sektor unggulan sesuai dengan permintaan pasar dan potensi wilayah.

Menurut penelitian yang dilakukan oleh Islami (2017) dengan judul pengembangan kawasan perdesaan berbasis komoditi hortikultura tersebut berada di kuadran I (mendukung strategi agresif). Strategi kuadran I (SO-Strategis) merupakan keadaan yang sangat menguntungkan, karena mempunyai kekuatan dan peluang dalam pengembangan kawasan berbasis komoditi hortikultura.

Uraian di atas sesuai dengan perbandingan hasil penelitian. Menurut Rangkuti (2008), matriks SWOT menggambarkan secara jelas peluang dan ancaman ekternal yang dihadapi kawasan perdesaan dapat disesuaikan dengan kekuatan dan kelemahan yang dimiliki. Matriks ini dapat menghasilkan empat set kemungkinan alternatif strategi, yaitu S-O (Strengths-Opportunity), S-T (StrengthsThreats), W-O (Weakness-Opportunity) dan W-T (Weakness-Threats). Menurut Jogiyanto (2005) adalah suatu penilaian atas kelemahan-kelemahan dan kekuatankekuatan dari semua sumber daya yang dimiliki oleh organisasi. Hal ini juga mencakup tantangan yang akan dihadapi dan kesempatan eksternal ke depannya.

\section{KESIMPULAN}

\section{Kecamatan Amuntai Utara} memiliki komoditas tanaman pangan tanaman padi bernilai 1 berarti sektor non basis/tidak memiliki keunggulan komparatif, tanaman jagung bernilai 2,25 berarti sektor basis dan tanaman kacang hijau bernilai 5,35 berarti sektor basis/memiliki keunggulan komparatif, komoditas tamanan tersebut tidak hanya saja dapat memenuhi kebutuhan konsumsi diwilayahnya tetapi juga dapat mengekspor ke luar kecamatan lain, kecuali dengan komoditas tanaman kacang tanah merupakan sektor non basis.

Analisis Shift Share menunjukkan komoditas tanaman pangan padi dengan nilai 0,12 dan jagung dengan nilai 0,56 di Kecamatan Amuntai Utara yang menunjukkan bernilai positif $(+)$ artinya komoditas tanaman padi dan jagung dikatakan sektor kompetitif jadi tanaman tersebut bisa bersaing dengan jenis yang sama di kecamatan lainnya. Sedangkan untuk komoditas lain seperti kacang tanah dan kacang hijau yang menunjukkan bernilai negatif (-) artinya komoditas tanaman kacang tanah dan kacang hijau dapat dikatakan tidak dapat bersaing dengan komoditas tanaman yang sama di kecamatan lain, atau sektor non kompetitif

Analisis SWOT diperoleh nilai dari analisis faktor internal (IFAS) sebesar 2,832 dan analisis faktor eksternal (EFAS) 
sebesar 2,45, maka pengembangan kawasan perdesaan berbasis tanaman pangan tersebut berada di kuadran I (mendukung strategi agresif). Strategi kuadran I (SO-Strategis) merupakan keadaan yang sangat menguntungkan, karena mempunyai kekuatan dan peluang dalam pengembangan kawasan berbasis tanaman pangan.

\section{DAFTAR PUSTAKA}

Burano, R.S., (2017). Pengembangan kawasan pedesaan berkelanjutan berbasis pertanian lahan basah. Jurnal Pertanian Faperta UMSBI(1), 25-34.

Dinas Pertanian Kabupaten Hulu Sungai Utara. (2018). Tanaman Pangan dan Hortikultura. Amuntai: Dinas Pertanian Kabupaten Hulu Sungai Utara.

Islami, N. (2017). Pengembangan Kawasan Perdesaan Berbasis Komoditi Hortikultura Di Kecamatan Ma'rang Kabupaten Pangkajene dan
Kepulauan.

(Skripsi).

Makassar: UIN Alauddin.

Heldawati \& Maisyarah, S. (2017). Analisis Keunggulan Komperatif (Comperative Advantage) Sektor Peternakan di Kabupaten Hulu Sungai Utara. Rawa Sains : Jurnal Sains STIPER Amuntai, 7(2), 88-94. DOI: 10.36589/rs.v7i2.78.

Rangkuti, F. (2008). Analisis SWOT Teknik Membedah Kasus Bisnis. Jakarta: PT Gramedia Pustaka Utama.

Rustiadi, E., Saefulhakim, S. \& Panuju. (2018). Perencanaan dan Pengembangan Wilayah. Jakarta: Crestpent Press dan Yayasan Obor Indonesia.

Sugiyono (2012). Metode Penelitian Bisnis Edisi II. Bandung: Alfabeta.

Tarigan, R. (2005). Ekonomi Regional Teori dan Aplikasinya. Jakarta: Bumi Aksara. 